\title{
Mevlânâ'ya atfedilen mülemma bir gazel üzerine
}

\section{Cenk AÇIKGöZ}

APA: Açıgöz, C. (2019). Mevlânâ'ya atfedilen mülemma bir gazel üzerine. RumeliDE Dil ve Edebiyat Araşturmaları Dergisi, (15), 242-252. DOI: 10.29000/rumelide.580559

\section{$\ddot{O} \mathbf{z}$}

Mevlânâ Celâleddîn-i Rûmî, genellikle Farsça şiirler yazmayı tercih etse de sanatı ve fikirleriyle klasik Türk edebiyatını derinden etkilemiştir. Mevlânâ çok sayıda eseri bulunan üretken bir şahsiyettir. Buna rağmen, bazen Mevlânâ'ya ait olmayan şiirler de Mevlânâ'ya atfedilmiştir. Bu çalışmamızda, Mevlânâ’ya atfedilen mülemma bir gazelin Mevlânâ'ya aidiyeti tekrar değerlendirilmiştir. Birçok kitap ve makalede Mevlânâ’ya ait olduğu belirtilen bu mülemma gazelin Şeyhî Divanı'nda da bulunduğu tarafımızdan ortaya konmuştur. Çalışmamız bir giriş bölümü, üç ana bölüm ve bir sonuç bölümünden meydana gelmiştir. Giriş bölümünde, bazen klasik Türk edebiyatının temel kaynaklarında aynı şiirlerin farklı şairlere ait gösterildiği belirtilmiş ve bu duruma örnekler verilmiştir. Ardından Mevlânâ Celâleddîn-i Rûmî̀ye atfedilen bazı şiirlerde de benzer sorunlarla karşılaşıldığı belirtilmiş, makalemizin konusu olan mülemma gazel üzerinde kısaca durulmuştur. Birinci bölümde, Mevlânâ'nın gazellerini ele alan ilmî yayınlarda, Mevlânâ'ya atfedilen mülemma gazele yönelik yaklaşımlar ele alınmıştır. İkinci bölümde, bahsi geçen gazelin Türk Edebiyatı Numuneleri ve Şeyhî Divanı adlı eserlerde bulunan şekilleri üzerinde durulmuştur. Üçüncü bölümde, gazeller arasındaki nüsha farkları ve gazellerin dayandırıldığı kaynaklar değerlendirilmiştir. Çeşitli araştırmacıların konuya yaklaşımlarından hareketle gazelin kime ait olduğu ortaya çıkarılmaya çalışılmıştır. Ayrıca gazelin gerçek sahibi hakkındaki düşünce ve tahminler sıralanmıştır. Sonuç bölümünde, araştırma sırasında karşılaşılan sorunlara ve araştırmadan elde edilen faydalara değinilmiştir.

Anahtar kelimeler: Mevlânâ, Şeyhî, mülemma, gazel, Dîvân-ı Kebîr.

\section{On a mulemma ghazal attributed to Mevlana}

\begin{abstract}
Although Mevlana Celaleddin-i Rumi preferred to write Persian poems, he deeply influenced classical Turkish literature with his art and ideas. Mevlana is a productive figure with many works. Nevertheless, poems which do not belong to Mevlana are sometimes attributed to Mevlana. In this study whether a mulemma ghazal attributed to Mevlana really belongs to him was reevaluated. In many books and articles, it is stated that this mulemma ghazal belongs to Mevlana. But it was revealed by us that this mulemma ghazal was also found in the Şeyhi's Divan. Our study consists of an introduction part, three main parts and a conclusion part. In the introduction part, it is stated that sometimes the same poems are shown as belonging to different poets in the basic sources of classical Turkish literature and examples are given. Then, some of the poems attributed to Mevlana Celaleddin-i Rumi have been mentioned and mulemma ghazal was briefly discussed. In the first part, in the scientific studies that dealt with Mevlana's ghazals, the approaches to mülemma ghazal attributed to Mevlana was discussed. In the second part, the forms of these ghazals in the works like
\end{abstract}


Turk Edebiyatı Numuneleri and Şeyhi Divanı. In the third part, the differences between these ghazals and resources were reevaluated. It has been tried to find out whom ghazal belongs to by various researchers. In addition, opinions and estimates about the actual owner of ghazal are listed. In the conclusion section, the problems encountered during the research and the benefits obtained from the research are discussed.

Keywords: Mevlana, Şeyhi, mulemma, ghazal, Divan-ı Kebir.

\section{Giriş}

Çeşitli kaynaklarda bir şiirin birden fazla şaire atfedilmesi klasik Türk şiiri araştırmalarında karşılaşılan önemli sorunlardandır. Birçok divan ve mecmuada aynı şiirlerin farklı şairlere ait gösterildiği görülmektedir. Böyle durumlarda şiirlerin kime ait olduğunu tespit etmek zorlaşmaktadır. Şiirlerin geçtiği nüshaların istinsah tarihleri ile şairlerin doğum-ölüm tarihlerine bakmak şiirin gerçek sahibini bulmaya yardımcı olabilir. Buna göre, şiirin bulunduğu nüsha, şiirin atfedildiği şair doğmadan önce istinsah edilmişse ortada bir hata vardır; yani o şiir, atfedildiği şaire ait olamaz. Bu kural genellikle, farklı yüzyıllarda yaşamış ama şiirleri karıştırılan şairler söz konusu olduğunda işe yaramaktadır. Mesela Fuzûlî’nin Türkçe divanındaki XXV. gazelin aslında Nesîmîye ait olduğu bu yöntemle ortaya çıarılmıştır (Açıkgöz, 2018, s. 40-41). Bahsi geçen gazelin matla beyti şudur:

Çünkim gözüme gelmedi hergiz ḩayāl-i ḩāb

Sāḳi getür piyāle vü doldur şarāb-i nāb

(Akyüz vd., 1958, s. 149)

Aynı yüzyılda yaşamış şairlerin karıştırılan şiirlerini ayırt etmek ise çok daha zordur. Şairlerin karıştırılan şiirlerini birbirinden ayırmak için dil ve üslup özelliklerinin veya işledikleri konuların değerlendirmesi çoğu kez yeterli olmamaktadır; çünkü aynı yüzyıllarda yaşamış şairler genellikle birbirine yakın bir dil kullanmış ve benzer konuları ele almıştır. Bunun gibi durumlarda nüshaların güvenirliğini ve sayısını dikkate alarak değerlendirmelerde bulunmak yerindedir. Buna rağmen gazellerin gerçek sahipleri hakkında kesin bir hükme varmak zordur; genellikle gazelin muhtemel sahibi ortaya konabilir. Kaynaklarda Rahîkî ve Figânî’ye ait gösterilen ama Hayâlî Bey Divanı'nın Harfü'l-Yâ' bölümüne alınmış olan 95 ve 96. gazeller bu duruma örnektir. Kuvvetli bir ihtimalle bu gazellerin ilki Rahîkîye ve ikincisi ise Figânî̀ye aittir; ama bu konuda kesin bir çıkarımda bulunmak şu an için mümkün görünmemektedir (Açıkgöz, 2017, s. 2-8). Bahsi geçen iki gazelin matla beyitleri şöyledir:

Kūh-kenlikler ki Ferhād ètdi çekdi miḥneti

'Işṣ-bāzīlik degülmiş bildüm anuñ niyyeti

(Tarlan, 1945, s. 438)

Sevdi göñlüm bāg̀-1 ḥüsnüñ bir gül-i ḩandānını

İñledür ḩār-1 belāda bülbül-i nālānını

(Tarlan, 1945, s. 438)

Şiirleri başka şairlerin şiirleriyle karıştırılmış olan önemli bir şahsiyet de Mevlânâ Celâleddîn-i Rûmî’dir. Mevlânâ'nın kullandığı mahlasların başka şairlerin mahlaslarıyla karıştırılması, başka şairlere ait şiirlerin özellilkle Mevlânâ'nın şiirleri arasına alınması ve Şiiliğin öne çıkarılmasına yönelik birtakım 
çabalar nedeniyle, Mevlânâ'ya ait olmayan birçok şiirin Dîvân-ı Kebîr'e karıştığı belirtilmektedir (Fürûzanfer, 2005, s. 180-185). İranlı Mevlânâ uzmanı Prof. Bedîuzzamân Fürûzanfer, Dîvân-ı Kebîr'in 9 eski yazmasını karşılaştırarak Mevlânâyya ait olmayan gazelleri önemli ölçüde ayıklamıştır. Eserin rubailer bölümünde Mevlânâ'ya ait olmayan rubailer de bulunduğunu ve bunlar üzerinde daha sonra tekrar çalışacağını belirtmiştir; ama buna ömrü yetmemiştir (Şafak, 2009, s. 76).

Mevlânâ'ya ait olmadı̆̆ hâlde ona ait gösterilen şiirler hâlâ tartışmalara yol açmaktadır. Mesela Dr. Yakup Şafak, Mevlânâ'ya atfedilen ve "Yine gel..." diye başlayan meşhur rubainin Mevlânâ'ya ait olma ihtimalini zayıf bulmaktadır (Şafak, 2009, s. 80). Biz de Mevlânâ’nın şiirlerinden örnek vermek amacıyla birçok edebiyat tarihinde ve Mevlânâ ile ilgili çoğu kitapta alıntılanmış olan bir mülemma gazelin Mevlânâ'ya aidiyetinden şüphe duyuyoruz. Bu gazel; Hıfzı Tevfik Gönensay, Hamamizade İhsan ve Hasan Âlî Yücel tarafından yazılan Türk Edebiyatı Numuneleri adlı edebiyat tarihinin 1. cildinde Mevlânâ Celâleddîn-i Rûmîyye ait gösterilmiştir (Gönensay vd., 1926, s. 136-137). Daha sonra Türk Edebiyat Numuneleri kaynak gösterilerek birçok başka esere de alınan bu mülemma gazelin Mevlânâ'ya aidiyeti kesin değildir; çünkü bahsi geçen gazel Şeyhî Divanı'nda CLXXI. gazel olarak yer almaktadır. Bu gazelin matla beyti şudur:

Māhest ne-mī-dānem huurşīid ruhet yā ne

$\mathrm{Bu}$ ayrılık odına nice cigerüm yana

(Gönensay vd., 1926, s. 136)

Bu karışıklı̆̆a dikkat çekmek, Mevlânâ’nın şiirlerini alıntılayacak araştırmacıları uyarmak ve konuyu ilim âleminin dikkatine sunmak amacıyla bu makaleyi yazmayı düşündük. Çalışmamızda önce, bahsi geçen gazelin Mevlânâ'nın gazellerini ele alan çalışmalarda bulunup bulunmadığını inceledik. Sonra da gazelin, Türk Edebiyatı Numuneleri ve Şeyhî Divanı'ndaki şekillerini karşılaştırarak gerçek sahibi hakkında fikir yürütmeye çalıştık.

\section{Mevlânâ'nın gazellerini ele alan yayınlar ve Mevlânâ'ya atfedilen mülemma gazel}

Mevlânâ'nın gazelleri Dîvân-ı Kebîr adı verilen hacimli eserinde yer almaktadır. Bu eser Dîvân-ı Şemsi Tebrîzî, Külliyât-ı Şems adlarıla da anılmaktadır (Karaismailoğlu, 2015, s. 9). Bu eserin tenkitli metnine dair en muteber yayın İran'da Prof. Bedîuzzamân Fürûzanfer tarafindan ortaya konmuştur. Fürûzanfer'in Kulliyât-ı Şems yâ Dîvân-ı Kebîr adlı 10 ciltlik yayınında divandaki gazeller kafiyelerinin son harflerine göre sıralanmıştır. Mevlânâ'ya atfedilen mülemma gazel "hâ"” harfiyle kafiyelendiğinden -bu yayında bulunması hâlinde- "Harfü'l-Hâ" bölümünde yer almalıdır. Oysa "Harfü’l-Hâ”" bölümü tarandığında bahsi geçen gazelin bu yayına alınmadığı görülmektedir (Fürûzanfer, 1339, s. 99-181). Fürûzanfer bu gazeli Mevlânâ'ya ait saymadı̆̆g için divana almamış olabilir.

Abdülbâki Gölpınarlı, Mevlânâ'nın Dîvân-ı Kebîr'ini Türkçeye tercüme etmiştir; Türkiye'de Dîvân-ı Kebîr denince akla ilk gelen eserlerden biri de bu 7 ciltlik tercümedir. Bu eser bir tenkitli metin değil, bir tercüme olduğu için eserde gazellerin Farsça olan asli şekilleri bulunmamaktadır. Bu çalışmanın hazırlanmasında kullanılan Mevlânâ Müzesi Müzelik Yazma Eserler Numara 68 ve 69'da bulunan Dîvân-ı Kebîr yazması, Abdülbâki Gölpınarlıya göre "nüshaların en sağlamı, en doğrusu ve en tamıdır." (Gölpınarlı, 1957, s. X) Bu nedenle, Mevlânâ’ya atfedilen mülemma gazeli araştırırken hem bu tercümeyi hem de bu tercümenin dayandığı yazmayı incelemek önem taşımaktadır. 
Bahsi geçen Dîvân-ı Kebîr yazmasında gazeller, aruz bahirlerine göre sıralanmıştır. Abdülbâki Gölpınarlı da bu düzene uyarak gazelleri aruz bahirlerine göre sıralanmış bir hâlde tercüme etmiştir. Mevlânâ'ya atfedilen mülemma gazel, "bahr-i hezec-i ahreb"in "Mef'ûlü mefâ'îlün mef' ûlü mefâ îlün" kahıbıyla yazılmıştır. Öyleyse bahsi geçen gazel -bu tercümede bulunması hâlinde- "bahr-i hezec-i ahreb"e ayrılan bölümde yer almalıdır; ama bu bahre ayrılan bölümde bu gazelin tercümesi bulunmamaktadır (Gölpınarlı, 1992, s. 3-276).

Abdülbâki Gölpınarlı’nın Dîvân-Kebîr tercümesinde esas aldığı yazma nüsha çok değerli sayıldığı için bu yazma nüshanın birkaç kez tıpkıbasımı yapılmıştır. T.C. PTT Genel Müdürlüğü tarafından 2012'de yayımlanan tıpkıbasım, yazmanın aslına en uygun olduğu düşünülen tıpkıbasımıdır. Yazmanın "bahr-i hezec-i ahreb" ile yazılan gazellere ayrılmış bölümü incelendiğinde, Mevlânâ'ya atfedilen mülemma gazelin bu önemli yazma nüshada da bulunmadığı görülmektedir (Çıpan, 2012, s. 34a-51a).

Mevlânâ'nın Türkçe şiir, beyit ve mısralarını bir araya getirmek amacıyla ortaya konan çalışmalarda da Mevlânâ'nın mülemma gazellerine yer verilmiştir. Ord. Prof. Dr. M. Şerefeddin Yaltkaya tarafından yayımlanan Mevlânâ'da Türkçe Kelimeler ve Türkçe Şiirler adlı kitap bu çalışmaların başında gelir. Bu çalışmanın ikinci kısmında, Mevlânâ'ya atfedilen mülemma gazel de bulunmaktadır. Yaltkaya, gazeli alıntılarken Hıfzı Tevfik Gönensay, Hamamizade İhsan ve Hasan Âlî Yücel tarafından yazılan Türk Edebiyat Numuneleri adlı edebiyat tarihini kaynak göstermiştir. Bununla birlikte, Türk Edebiyatı Numuneleri"ndeki gazelin 5. mısrasında geçen "tame" kelimesini yanlış bulmuş, kelimenin "tane" olması gerektiğini belirtmiştir (Yaltkaya, 1934, s. 50-51). Yaltkaya’nın Mevlânâ’ya atfedilen mülemma gazeli makalesine alırken Türk Edebiyatı Numuneleri’ni kaynak göstermesi, Türk Edebiyatı Numuneleri’nde ise bu gazelin hangi kaynaktan alındığının belirtilmemiş olması dikkat çekicidir (Gönensay vd., 1926, s. 136-137).

Prof. Dr. Mecdut Mansuroğlu, Mevlâna Celâleddin Rumî'de Türkçe Beyit ve İbareler adlı makalesinde, Ord. Prof. Dr. M. Şerefeddin Yaltkaya'nın Mevlânâ'da Türkçe Kelimeler ve Türkçe Şiïler adlı kitabına yönelik önemli eleştirilerde bulunmuş ve Mevlânâ'nın Türkçe beyitlerini yeniden bir araya getirmeye çalışmıştır. Mansuroğlu'na göre Yaltkaya, Mevlânâ'ya "dil, sanat, eda ve konu bakımlarından uzak düşen bazı Türkçe beyitleri de Celâleddin Rumî’nin olarak tanıtmıştır.” (Mansuroğlu, 1954, s. 208) Mansuroğlu, Yaltkaya'nın Mevlânâ'ya ait gösterdiği bazı şiirleri Mevlânâ'ya ait saymamış ve bunları kendi makalesine almamıştır. Bu konudaki görüşlerini şöyle ifade etmiştir: "Celâleddin Rumî’deki Türkçe beyit ve ibareler eski veya eskilikleri bozulmamış yazmalara dayanılarak bir daha elden geçirilmiştir. Bu suretle M. Şerefeddin'ce şairimize tanınan 17 Türkçe ve Türkçe-Farsça manzumeden ancak 10 tanesinin bu vasfı taşıyabileceği görülmüştür.” (Mansuroğlu, 1954, s. 208) Makalemizin konusu olan mülemma gazel, Yaltkaya tarafindan Mevlânâ'ya ait gösterildiği hâlde Mansuroğlu tarafından Mevlânâ'nın şiirleri arasından çıkarılmış 7 şiirden biridir (Mansuroğlu, 1954, s. 209-218). Mansuroğlu, bu gazelin asıl kaynağının hangi yazma olduğu, bu kaynağın güvenilir olup olmadığı ve gazelin Mevlânâ’ya ait değilse kime ait olduğu konuları üzerinde durmamıştır.

Prof. Dr. Hasibe Mazıoğlu Mevlânâ Celâleddîn-i Rûmînin Türkçe Şïrleri adlı makalesinde Mevlânâ’nın beyit ve şiirlerinden bazı örnekler vermiştir. Mazıŏglu "Mevlânâ'nın bir mülemma'ını da Türkçe dizelerinin güzelliği nedeniyle buraya aldım.” diyerek makalemizin konusu olan mülemma gazele de makalesinde yer vermiştir. Bu gazeli alıntılarken hem Türk Edebiyatı Numuneleri'ni hem Sadettin Nüzhet Ergun'un Mevlânâ adlı kitabını hem de Asaf Hâlet Çelebi'nin Mevlâna (Hayatı - Şahsiyeti Eserlerinden Parçalar) adlı kitabını kaynak göstermiştir (Mazıŏglu, 2007, s. 816). Bahsi geçen gazel, Asaf Hâlet Çelebi'nin Mevlânâ (Hayatı - Şahsiyeti - Eserlerinden Parçalar) adlı kitabına da aslında 
Türk Edebiyatı Numuneleri kaynak gösterilerek alınmıştır (Çelebi, 1939, s. 146). Sadettin Nüzhet Ergun'un Mevlânâ adlı kitabında ise “Mevlâna'nın Türkçe Manzumeleri” başlığı altında bir bölüme yer verilmiş, bu bölümün başında Mevlânâ’nın Türkçe şiirlerinin Türk Edebiyat Numuneleri de dâhil olmak üzere birçok yayında bulunduğu belirtilmiştir (Ergun, 1932, s. 39-50). Bahsi geçen müllemma gazel ise hangi kaynakta bulunduğu açıkça belirtilmeden kitaba alınmıştır (Ergun, 1932, s. 44).

Anlaşıldığı kadarıyla kimi araştırmacılar, Mevlânâ'ya atfedilen mülemma gazeli bazen doğrudan Türk Edebiyat Numuneleri'ni kaynak göstererek, bazen de Türk Edebiyatı Numuneleri’ni kaynak gösteren diğer araştırmacılara atıfta bulunarak kendi yayınlarına almışlardır. Böylece Türk Edebiyatı Numuneleri’nde Mevlânâ'ya atfedilen mülemma gazel hem kitaplara hem de makalelere geçerek her yere yayılmış ve bu gazelin Mevlânâ'ya aidiyetinden şüphe duyulmamıştır. Bahsi geçen gazelin araştırmacılar tarafından beğenilmesi ve güzel bulunması da daha çok alıntılanması sonucunu doğurmuş, bu gazel neredeyse Mevlânâ ile ilgili her eserde örnek verilmeye başlanmıştır.

Bizce bu gazelin Mevlânâ'ya aidiyetine şüpheyle yaklaşmak gerekir; çünkü Mevlânâ'ya ait olduğu iddia edilen bu gazelin Şeyhî Divanı'nda da bulunduğu (Biltekin, 2003, s. 225-226) tarafımızdan ortaya konmuştur.

\section{Mevlânâ'ya atfedilen mülemma gazel ve Şeyhî Divanı'ndaki CLXXI. gazel}

Hıfzı Tevfik Gönensay, Hamamizade İhsan ve Hasan Âlî Yücel tarafından yazılan Türk Edebiyatı Numuneleri adlı edebiyat tarihinin 1. cildinde Mevlânâ Celâleddîn-i Rûmî̀ye, oğlu Sultân Veled ile aynı başlık altında yer verilmiştir (Gönensay vd., 1926, s. 135-142). Eserde, Mevlânâ Celâleddîn-i Rûmî hakkında verilen bilgilerin ardından onun şiirlerinden bazı parçalar da sunulmuştur. Daha sonra "Şu iki mülemma, Mevlânâ'nın Türkçe yazıları içinde belki en güzel olanlarıdır." denmiş, Mevlânâ'ya ait olduğu belirtilen iki gazel sıralanmıştır. Örnek verilen gazellerin ilki, makalemizin de konusu olan mülemma gazeldir. Bahsi geçen gazelin hangi kaynaktan alındığı belirtilmemiştir (Gönensay vd., 1926, s. 136-137). Bu gazel, tarafımızdan Latin harflerine aktarılmış şekliyle, aşağıya aynen alınmıştır.

\section{[Ġazel-i Mülemma` ]}

\section{Mef ūlü Mefă‘ ìlün Mef àlü Mefă ìilün \\ Hezec- -./. - - -/- -./. - -}

1. Māhest ne-mī-dānem huurşìd ruhet yā ne

$\mathrm{Bu}$ ayrılıḳ odına nice cigerüm yana

2. Mürdem zi-firāḳ-1 tū merdüm ki heme dāned

'Iş̧̣ odı nihān olmaz yanar düşecek cāna

3. Sevdā-y1 ruh̆-1 Leylī şod ḥāṣıl-1 mā haylì

Mecnūn bigi vāveylì oldum gene dīvāne

4. $\quad$ Sad tīr zened ber-dil ān Türk-i kemān-ebrū

Fitnelü elā gözler çün uyḩudan uyana

5. Ey şāh Şücā‘ ü’d-dīn Şemsü'l-Ḥaḳ-1 Tebrīzì

Raḥmetden eger n'ola bir ḳațre bize țama 
Dr. Halit Biltekin, Şeyhî Divanı'nı 2003'te doktora tezi olarak sunmuş, 2018'de ise e-kitap şeklinde yayımlamıştır. Şeyhî’nin bahsi geçen gazeli doktora tezinde CLXX. gazel, yayında ise CLXXI. gazel olarak numaralandırılmıştır. Şeyhî Divanı'nın Dr. Halil Biltekin tarafından hazırlanan yayınında, doktora tezindeki şiirlerde karşılaşılan bazı eksiklerin giderildiği, beyitlerdeki bazı kelimelerin düzeltildiği ve divana yeni şiirler eklendiği anlaşılmaktadır. Bununla birlikte, gazellerin alındığı nüshaları ve gazeller arasındaki nüsha farklarını gösteren dipnotlar yeni yayından kaldırılmıştır. Ayrıca divanın tenkitli metninin nasıl hazırlandığını aktaran ve nüsha tavsifi hakkında ayrıntılı bilgi veren kısımlar da yeni yayına alınmamıştır. Bu nedenle, incelediğimiz gazelin bulunduğu nüshaya ait bilgileri doktora tezine dayanarak aktardık. Gazeli alıntılarken ise gazelin yeni yayındaki gözden geçirilmiş ve düzeltilmişs son şeklini kullandık. ${ }^{2}$

Dr. Halit Biltekin, Şeyhî Divanı'nın tenkitli metnini hazırlarken 7 divan nüshasını karşlaştırmış, nüshaları karşılaştırırken hiçbir divan nüshasını esas almamıştır (Biltekin, 2003, s. 8). Bu divandaki CLXX. gazeli sadece bir Şeyhî Divanı nüshasına dayandırmıştır (Biltekin, 2003, s. 225). Bu nüsha ve kısaltması şudur: K - Mısır Kahire Millî Kütüphanesi, No: 1811 (Biltekin, 2003, s. 3).

Bahsi geçen nüshanın istinsah tarihi belli değildir (Biltekin, 2003, s. 6). Nüsha 71 varaktır; altın yaldız cetvelle çevrilidir ve 15 satırlı harekesiz nesih hatla yazılmıştır. Yazmanın başında ve sonunda okunamayan bir mühür bulunmaktadır. Bu nüshada 14 kaside, 4 tercî́-bend, 2 terkîb-bend, 1 müstezat ve 149 gazel vardır. Bu nüshada yer alan kasideler ve musammatlar karışık olarak verilmiş, gazeller bölümünde olması gereken " $\mathrm{z}$ " ve " $\mathrm{r}$ " kafiyeli birer gazel ise kasideler ve musammatların arasına alınmıştır. Bu nüshadaki 2 gazel, karşılaştırmalı metin hazırlanırken kullanılan diğer nüshalarda yoktur (Biltekin, 2003, s. 3-4).

Şeyhî Divanı'nın "K" nüshasında geçen ama diğer nüshalarında bulunmadığı belirtilen 2 gazelden biri, makalemizin konusu olan CLXX. gazeldir. Bu gazel $\mathrm{K}$ nüshasının 63a numaralı sayfasında bulunmaktadır (Biltekin, 2003, s. 225-226). Şeyhî Divanı'nın 2018'deki yayınında da CLXXI. gazel olarak adlandırılmıştır (Biltekin, 2018, s. 178). Bahsi geçen CLXXI. gazel aşağıya aynen alınmıştır.

\section{CLXXI}

\section{Mef ūlü Mefā'î̀ün Mef ūlü Mefā'ìlün}

Hezec- -./.---/.-./.--

1. Māhest ne-mì-dānem huūrşīid ruhet sāye

Bu ayrulıg odına cānum niçe bir yana

2. Mürdem zi-firāke-1 to merdüm heme mī-dāned

'Iş̧ odı nihān olmaz yanduḳca*irişür cāna

3. $\quad$ Ān rūZ-1 vis̄ālet-rā men ḳadr ne-dānistem

Her gice yanar bağrum döner yüregüm ḳana

\footnotetext{
2 Şeyhî Divanı'nın Prof. Dr. Mustafa İsen ve Prof. Dr. Cemâl Kurnaz tarafından hazırlanan bir yayını daha vardır. Bu yayına alınan şiirlerin hangi divan nüshalarında geçtiği açıkça belirtilmemiş ve şiirlerdeki nüsha farkları gösterilmemiştir. Metin hazırlanırken çeviri yazı alfabesi kullanılmamış ve şiirlerin yazıldığı devrin dil ve imla özelliklerine uyulmamıştır. Bu yayın ilmî ölçülere tam anlamıyla uyularak hazırlanmamış olsa da araştırmacıların başvurduğu önemli bir kaynaktır. Bu yayının "Harfü'l-Hâ"” ile yazılmış gazellere ayrılan kısmında, bahsi geçen mülemma gazel bulunmamaktadır (İsen ve Kurnaz., 1990, s. 243-264).
} 
4. Sevdā-yı ruh̆-1 Leylī şod hạașill-1 mā hayli

Mecnūn bigi vā-veylā oldum yine dīvāne

5. Pür nāfe şeved müş̧īn yekser heme der- ${ }^{\complement}$ ālem

Ol dem ki seherer yili zülfüñe ura şāne

6. S S Sad tīr zened ber-dil ān türk-i kemān-ebrū

Fitnelü elā gözler çün uyhudan uyana

7. Ez-lac 1-i lebet Şeyhīi üftād cüdā nā-geh

Ḥaḳdur ki döker gözüm yāḳūt ile dür-dāne

\section{Değerlendirme ve görüişler}

Bu bölümde Türk Edebiyatı Numuneleri’ni TEN, Dr. Halit Biltekin tarafindan yayımlanan Şeyhî Divanı'nı ise ŞD kısaltmalarıyla göstererek yukarıdaki gazeller hakkında fikir yürütmeye çalışacağız.

TEN'deki gazel 5, ŞD'deki CLXXI. gazel ise 7 beyitten meydana gelmektedir. İki gazel arasında 2 beyitlik fark bulunması ve ŞD'deki gazelin beyit bakımından daha zengin olması dikkat çeker.

TEN'deki gazelde ilk beytin 1. mısrasında "yā ne" ifadesi kullanılırken, ŞD'deki gazelin ilk beytinin 1. mısrasında bu ifade yerine "sāye" kelimesi kullanılmıştır. TEN'deki gazelde ilk beytin 2. mısrasında geçen "nice cigerüm" ifadesi ŞD'deki gazelin ilk beytinin 2. mısrasında "cānum niçe bir" şeklindedir. Mısralardaki "ayrulığ" ve "ayrılıḳ" kelimelerinin imlasındaki farklılık bir nüsha farkı sayılmazsa TEN'deki gazel ile ŞD’deki gazelin ilk beyitleri arasında sadece iki yerde fark olduğu anlaşılır.

TEN'deki gazelde 2. beytin 1. mısrasındaki "ki heme" ifadesi ŞD'deki gazelin 2. beytinin 1. mısrasında "heme mï-" şeklindedir. TEN'deki gazelde 2. beytin 2. mısrasındaki "yanar düşecek" ifadesi ŞD'deki gazelin 2. beytinin 2. mısrasında "yanduḳca*irişür" şeklindedir. Bu mısradaki "yanduḳca*irişür" ifadesinde kelimelerin arasına konan “*” işareti, kelimelerin vezin dolayısıyla birleştirilerek okunması ve ilk kelimenin son harfinin düşürülmesi gerektiğini belirtmektedir. Kısacası gazellerin 2. beyitleri arasinda sadece 3 kelimede fark bulunduğu görülmektedir.

TEN'deki gazelin 3. beyti ŞD'deki gazelin 4. beytidir. TEN'deki gazelin 3. beytinin 1. mısrası ile ŞD'deki gazelin 4. beytinin 1. mısrası aynıdır. TEN'deki gazelin 3. beytinin 2. mısrasında geçen "gene" kelimesi ŞD'deki gazelin 4. beytinin 2. mısrasında "yine" şeklindedir. TEN'deki gazelin 3. beytinin 2. mısrasında geçen "vāveylì" kelimesi ŞD'deki gazelin 4. beytinin 2. mısrasında "vā-veylā" şeklinde yazılmıştır. TEN'deki gazelin 3. beyti musammat gazellerin beyitleri gibi iç kafiyeli olduğundan "Leylī, haylī ve vāveylī" kelimelerinin imlasının uyumlu olmasına dikkat edilmiştir. "Vāveylī" ve "vā-veylā" kelimeleri arasındaki imla farkı bir nüsha farkı sayılmazsa bu beyitler arasında tek kelimelik fark olduğu söylenebilir.

TEN'deki gazelin 4. beyti ŞD'deki gazelin 6. beytidir. Bu iki beyit arasında hiçbir fark bulunmamaktadır. TEN'deki gazelin 5. beyti ŞD'deki gazelde yoktur; ŞD'deki gazelin 3, 5 ve 7. beyitleri ise TEN'deki gazelde yoktur.

TEN'deki gazelde 5. beyit mahlas beyittir; Mevlânâ, şiirlerinde dostlarının adını mahlas yerine kullandığından 5. beyitte geçen "Şemsü'l-Ḥaḳ-1 Tebrīīi” ifadesi Mevlânâ'nın bu gazeldeki mahlası olarak yorumlanabilir. ŞD'deki gazelin mahlas beyti ise 7. beyittir; beyitte "Şeyhī" mahlası geçmektedir. 
TEN'deki gazelde ŞD'deki gazelin 7. beytine benzeyen bir beyit yoktur. ŞD'deki gazelde de TEN'deki gazelin 5 . beyitine benzeyen bir beyit yoktur. Yani gazellerdeki karışıklık mahlas beyitlerde meydana gelmemiş ve mahlasların karıştırılması sonucunda ortaya çıkmamıştır.

Buna göre TEN'deki gazelin ve ŞD'deki gazelin mahlas beyitleri tamamen farklıdır. Ayrıca ŞD'deki gazel TEN'deki gazelden 2 beyit fazladır. İncelenen 4 beyit ise hem TEN'deki gazelde hem de ŞD'deki gazelde geçmektedir ve neredeyse aynıdır. Aslında ortada tek şaire ait bir gazel vardır ve bu gazelin tahrif edilerek başka bir şaire daha ait gösterildiği anlaşılmaktadır.

Gazelin gerçek sahibini bulmak için TEN'deki gazelin alındığı nüsha ile ŞD'deki CLXXI. gazelin alındığı nüsha incelenebilir. Ne yazık ki ŞD’deki gazelin alındığı K nüshasının istinsah tarihi belli değildir (Biltekin, 2003, s. 6). TEN'deki gazel ise esere kaynak gösterilmeden alınmıştır. TEN'den yararlanarak bahsi geçen şiiri eserlerine alanlar da sadece TEN’i kaynak göstermiş ve bu şiirin asli kaynağını, yani hangi yazmadan hareketle TEN'e alındığını belirtmemişlerdir. Bu nedenlerle, gazelin alındığı nüshaların istinsah tarihlerini Mevlânâ (ö. 1273) ve Şeyhî’nin (ö. 1429'dan sonra) ölüm tarihleriyle karşılaştırarak gazelin gerçek sahibi hakkında fikir yürütmek mümkün olmamaktadır.

ŞD’deki gazel, Mısır Kahire Millî Kütüphanesi, No: 1811'de bulunan tek nüshaya dayanılarak ŞD’ye alınsa dahi, en azından bir yazmada geçmektedir. TEN'de bulunan gazelin hangi yazmadan alındı $\breve{s}$ bile belli değildir. Bu durum gazelin Şeyhî̀ye ait gösterilmesini daha doğru kılar.

ŞD'deki gazel TEN'deki gazelden 2 beyit fazla olduğuna göre ŞD'deki gazelin asıl gazel olma ihtimali daha güçlüdür. Öyleyse bu gazelin Mevlânâ’ya değil, Şeyhî̀ye ait olma ihtimali de güçlenmektedir.

İncelenen gazel akıcı bir dille yazılmıştır. Türkçe mısralarda eski Anadolu Türkçesine uymayan kelimelerin bulunmaması ve aruz vezninin ustaca kullanılması dikkat çeker. Oysa Mevlânâ'nın (ö. 1273) yaşadığı XIII. yüzyıl, Anadolu'da aruzla ilk Türkçe şiirlerin yazıldığı dönemdir ve bu ilk denemeler hem aruzun kullanımı hem de dilin akıcllğ̆ yönünden pürüzlüdür. İncelenen gazelde geçen Türkçe mısralardan ise oturmuş ve son derece gelişmiş bir şiir geleneğinin, yüzyllara dayanan bir edebî birikimin izleri sezilmektedir. Bu gazel Türkçeyle şiir yazma girişimlerinin başını çeken Mevlânâ ve Sultân Veled gibi şairlerin dil, üslup ve aruz tasarruflarına uymayan özellikler taşımaktadır. Prof. Dr. Mecdut Mansuroğlu'nun bu gazeli Mevlânâ'ya ait saymaması ve Mevlâna Celâleddin Rumî'de Türkçe Beyit ve İbareler adlı makalesine almaması da (Mansuroğlu, 1954, s. 207-218) bu gazelin Mevlânâyya ait olma ihtimalini zayıflatmaktadır.

Ayrıca, Mevlânâ'ya atfedilen bu gazel hem Dîvân-ı Kebîr'in en muteber tenkitli metni sayllan Prof. Bedîuzzamân Fürûzanfer'in Kulliyât-ı Şems yâ Dîvân-ı Kebîr adlı yayınında hem de Abdülbâki Gölpınarlı'nın en doğru Dîvân-ı Kebîr nüshası saydığı ve tercüme ettiği Mevlânâ Müzesi Müzelik Yazma Eserler Numara 68 ve 69'da bulunan yazmada yoktur.

Cinuçen Tanrıkorur'un Osmanlı Dönemi Türk Mûsikîsi adlı eseri doğrudan Mevlânâ’nın gazellerini ele alan bir yayın değildir; ama bu yayının satır aralarında da bahsi geçen mülemma gazel hakkındaki tespitlerimizi destekleyen bazı önemli değerlendirmeler bulunmaktadır. Tanrıkorur, genellikle Mevlânâ'nın Farsça şiirlerinden oluşan Mevlevi ayini güfteleri arasına zamanla Mevlevî büyüklerinin Türkçe veya mülemma şiirlerinin de alındığını belirtmiş, buna örnek olarak da makalemizin konusu olan mülemma gazelin ilk beytini vermiştir. Ayrıca, herhangi bir kaynak göstermemekle birlikte, bu mülemmanın Mevlânâ'ya değil, Şeyhî̀ye ait olduğunu ifade etmiştir. Tanrıkorur, Mevlevi ayini 
güftelerinde Farsça, Türkçe ve Arapça şiirlerin iç içe kullanıldığını belirtir. "Mevleviliğin bir Türk tarikatı oluşu yüzünden, Farsçası zayıf olan, bu yüzden de Mevlânâ’nın olmayan şiirleri onun zannedip besteleyen" bestekârların bulunmasını da bu durumun sebepleri arasında sayar (Tanrıkorur, 2005, s. 122). Cinuçen Tanrıkorur'un bu tespitleri, bahsi geçen mülemma gazelin Şeyhî̀ye ait olduğu hâlde tahrif edildiği ve Mevlânâ'ya ait gösterildiği yönündeki düşünceleri desteklemektedir.

Prof. Bedîuzzamân Fürûzanfer de çeşitli Dîvân-ı Kebîr nüshalarında dahi birçok gazelin Mevlânâ’nın olmadığı hâlde Mevlânâ’ya ait gösterildiğini belirtmiştir. Bu gazellerin Mevlânâ'ya ait olduğunu gösterebilmek için de sonlarına Şems mahlasını ihtiva eden beyitler eklendiğini ifade etmiştir. Mesela Isfahanlı Cemâleddîn, Tabaslı Şemseddîn, Enverî hatta Mevlânâ'nın oğlu Sultân Veled'e ait gazeller dahi Dîvân-ı Kebîr'e alınmıştır (Fürûzanfer, 2005, s. 180-181). Anlaşıldığı kadarıyla başka şairlerin gazellerine Şems mahlası geçen bir beyit katarak gazelleri Mevlânâ'ya atfetmek sıklıkla karşılaşılan bir durumdur. $\mathrm{Bu}$ durum makalemizin konusu olan gazelin de aynı akıbete uğradığı fikrini akla getirmektedir.

Yukarıdaki bilgilere dayanarak Şeyhî’nin gazelinin tahrif edildiğini, gazelin 2 beyit kısaltıldığını, gazeldeki mahlas beytin ortadan kaldırıldığını ve gazele başka bir mahlas beyit eklendiğini tahmin ediyoruz. Kesin bir hükme varmaktan kaçınmakla birlikte bu gazelin Mevlânâ’ya değil, Şeyhîye ait olma ihtimalinin daha güçlü olduğunu düşünüyoruz.

\section{Sonuç}

Dîvân-ı Kebîr, Mevlânâ'nın en önemli eserleri arasında yer alır. Prof. Bedîuzzamân Fürûzanfer bu esere karışan ama Mevlânâ'ya ait olmayan gazel ve rubailer hakkında uyarılarda bulunmuştur; buna rağmen bazı gazel ve rubailerin Mevlânâ’ya aidiyeti hakkındaki sorunlar hâlâ tamamen çözülememiştir.

Dîvân-ı Kebîr'in en muteber tenkitli neşri İranlı araştırmacı Prof. Bedîuzzamân Fürûzanfer tarafından ortaya konmuştur. Mevlânâ, Anadolu'da yetişmiş bir Türk şairi sayıldığı hâlde Dîvân-ı Kebîr'in Türkiye'de ilmî bir neşrinin bulunmaması dikkat çekmektedir. Bu durum Türkiye'de Dîvân-ı Kebîr'in tenkitli metnini temin etmek isteyenlerin işini zorlaştırmaktadır.

Mevlânâ'nın şiirlerini aslından araştırmak isteyenler bir yandan Prof. Bedîuzzamân Fürûzanfer’in hazırladığı tenkitli neşre, bir yandan Mevlânâ Müzesi Müzelik Yazma Eserler Numara 68 ve 69'da bulunan yazmaya, bir yandan da Abdülbâki Gölpınarlı'nın tercümesine bakmak zorunda kalmaktadır. Öyle ki Prof. Dr. Adnan Karaismailoğlu tarafından, son derece hacimli olan bu yayınları karşılaştıranların yükünü hafifletmek için, bu üç yayını kullanma kılavuzu niteliği taşıyan bir dizin bile hazırlanmıştır. Dîvân-ı Kebîr'deki şiirlerin hem Farsça orijinal şekillerini hem Latin harfli çeviri yazılı metinlerini hem de bugünkü Türkçeye tercümelerini yan yana veren bir yayın hazırlanması en büyük temennimizdir. Böyle bir yayının hazırlanması zordur; ama Mevlânâ’nın şiirlerini aslından görmek isteyenlere, Farsça öğrenenlere ve araştırmacılara sağlayacağı kolaylık çok büyük olacaktır. Ayrıca böyle bir yayın Anadolu'da yetişen bir şahsiyetin eserlerine daha iyi sahip çıabilmek adına da önem taşımaktadır.

Şeyhî Divanı hem Prof. Dr. Muhsin Macit ve Prof. Dr. Cemâl Kurnaz tarafindan hem de Dr. Halit Biltekin tarafından yayımlanmıştır. Her iki yayında da şiirlerin alındığı nüshaları ve şiirler arasındaki nüsha farklarını belirten dipnotlar bulunmamaktadır. Bu durum, Şeyhî’nin şiirleri üzerine bilimsel araştırma yapmak isteyenlerin bu değerli çalışmalardan yeterince yararlanamamasına yol açmaktadır. 
Makalemizin konusu olan gazelin Mevlânâ'ya ait olmadığını düşündüren birçok bilgiye ulaşılmıştır. Bu gazelin Şeyhî Divanı'nında da bulunması bu bilgilerin başında gelmektedir. Buna rağmen gazelin Şeyhî Divanı nüshalarının çoğunda bulunmaması da düşündürücüdür. Böylesine dikkat çeken ve beğenilen bir gazelin Şeyhînnin şiirlerini ele alan kaynaklarda yeterince yer bulamaması, bu gazelin Şeyhî̀ye aidiyeti hakkındaki tereddütlerin tamamen giderilmesini engellemektedir. Bu yüzden, bahsi geçen gazelin Mevlânâ dışında bir şaire ait olup Şeyhî̀ye atfedilme ihtimali de akla gelebilir. Bu tereddütlerin tamamen ortadan kalkması için gazelin Şeyhî̀ye ait olduğunu gösteren daha çok kaynağa ulaşmak önem taşımaktadır.

Bu çalışmada, yıllarca çeşitli kitap ve makalelerde Mevlânâ’nın gazeli olarak sunulan mülemma bir gazelin kuvvetli bir ihtimalle Şeyhî̀ye ait olduğu ortaya konmuştur. Bu çalışmanın klasik Türk şiiri kaynaklarındaki karışıklıkların giderilmesine katkı sağlamasını dileriz.

\section{Kaynakça}

Açıkgöz, C. (2017). Hayâlî Bey dîvânı'nın harfü'l-yâ' bölümündeki 95 ve 96. gazeller kime ait?. Bilecik Şeyh Edebali Üniversitesi Sosyal Bilimler Enstitüsü Dergisi, 2, 1-8.

Açıkgöz, C. (2018). Fuzûlî’nin Türkçe divan'ındaki XXV. gazel Nesîmî̀ye mi ait?. Ü. Aslan, H. Taş ve Ö. Zülfe (Ed.). Bir devr-i kadîm efendisi Prof. Dr. Tahir Üzgör'e armă̆an içinde (s. 29-43). Ankara: Yayın Evi.

Akyüz, K., Yüksel, S., Beken, S. ve Cunbur, M. (1958). Fuzûlî Türkçe divan. Ankara: İş Bankası, Türk Tarih Kurumu Basımevi.

Ayan, H. (2014). Nesîmî hayatı, edebî kişiliği, eserleri ve Türkçe divanının tenkitli metni. Ankara: Türk Dil Kurumu Yayınları.

Biltekin, H. (2003). Şeyhî dîvânı (inceleme-tenkitli metin-dizin). Doktora Tezi, Ankara: Ankara Üniversitesi Sosyal Bilimler Enstitüsü.

Biltekin, H. (2018). Şeyhî dîvânı. Ankara: T.C. Kültür ve Turizm Bakanlı̆̆ı Kütüphaneler ve Yayımlar Genel Müdürlüğü. Erişim adresi: http://ekitap.kulturturizm.gov.tr/TR-215511/seyhi-divani.html (Erişim tarihi: 01.03.2019, saat: 21.35).

Çelebi, A. H. (1939). Mevlâna hayatı - şahsiyeti - eserlerinden parçalar. [İstanbul]: Kanaat Kitabevi.

Çıpan, M. (Ed.). (2012). Mevlânâ Celâleddîn Muhammed-dîvân-ı kebîr (tıpkıbasım) (1. Cilt). Ankara: T.C. PTT Genel Müdürlüğü Yayınları.

Ergun, S. N. (1932). Mevlâna. İstanbul: Kanaat Kütüphanesi.

Fürûzanfer, B. (1339). Kulliyât-ı Şems yâ dîvân-ı kebîr (5. Cilt). Tahran: İntişârât-ı Dânişgâh-ı Tehrân.

Fürûzanfer, B. (2005). Mevlâna Celâleddin Feridun Nafiz Uzluk (Çev.). Konya: T.C. Konya Valiliği İl Kültür ve Turizm Müdürlüğü.

Gölpınarlı, A. (1957). Mevlânâ Celâleddin dîvân-ı kebîr I (1. Cilt). İstanbul: Remzi Kitabevi.

Gölpınarlı, A. (1992). Mevlânâ Celâleddin dîvân-ı kebîr II (2. Cilt). Ankara: Kültür Bakanlığı Yayınları.

Gönensay, H. T., Hamamizade, İ. ve Yücel H. Â. (1926). Türk edebiyat numuneleri, menşelerden onuncu hicret asrma kadar (1. Cilt). İstanbul: Maarif Vekaleti Neşriyatından, Millî Matbaa.

İsen, M. ve Kurnaz, C. (1990). Şeyhî divanı. Ankara: Akçă̆ Yayınları.

Karahan, A. (1966). Kanuni Sultan Süleyman çağı şairlerinden Figanî ve divançesi. İstanbul: İstanbul Üniversitesi Edebiyat Fakültesi Yayınları.

Karaismailoğlu, A. (2015). Dîvân-ı kebîr gazel dizini - yazma, basma ve çeviriler için karşılaştırmalı dizinler-. Ankara: Akçağ Yayınları. 
Mansuroğlu, M. (1954). Mevlânâ Celâleddin Rumî’de Türkçe beyit ve ibareler. Türk Dili Araşttrmalar Yillı̆̆ Belleten, 207-220.

Mazıoğlu, H. (2007). Mevlânâ Celâleddîn-i Rûmînnin Türkçe şiirleri. Türk Dili-Dil ve Edebiyat Dergisi, XCIV/672, 811-822.

Şafak, Y. (2009). Mevlânâ’ya atfedilen “yine gel...” rubâîsine dair. Tasavvuf-ìlmî ve Akademik Araştırma Dergisi, 24, 75-80.

Tanrıkorur, C. (2005). Osmanlı dönemi Türk mûsikîsi (2. Baskı). İstanbul: Dergâh Yayınları.

Tarlan, A. N. (1945). Hayâlî Bey dîvânı. İstanbul: İstanbul Üniversitesi Yayınları.

Yaltkaya, M. Ş. (1934). Mevlânâ’da Türkçe kelimeler ve Türkçe şïrler. İstanbul: Remzi Kitaphanesi.

Zülfe, Ö. (2009). Rahîkî [ö. 953/1546] ve şiirleri. Türk Kültürü İncelemeleri Dergisi/The Journal of Turkish Cultural Studies, 21, 171-198. 